\title{
微小 $\mathrm{X}$ 線束による金属・セラミック接合界面近傍の 残留応力分布測定
}

\author{
田中 俊一郎*
}

\section{1. は じめに}

金属・セラミックス接合体の界面近傍には, 両者の熱膨 張係数差および弾性率差に起因する残留応力が接合後の冷 却過程で分布をもって生じる. セラミックスなどの脆性材 料ではこの残留応力が接合強度を支配する要因の一つとな るため，その軽減方法が開発課題となってきた ${ }^{(1)}$. 一方, 脆性材料であるセラミックス部に拈ける分布を把握する試 みがなされてきたが，それは連続体の力学やFEM. BEM などの数值解析によるものが主流であり, 結果を接 合構造設計に反映させることが一般的であった。この接合 体の残留応力解析に拈いては, 接合端近傍での最大主応力 位置や応力特異性などが特に問題となっていることは周知 であるが，これらの解析結果にはモデルや手法により様々 な矛盾が生じる場合もあり，また実際の接合製品では解析 に用いた理想モデルとは異なることもあった，

こうした解析上の問題に端的に答えるには, 細部の残留 応力分布を直接的に測定すればよいことは明らかである.

しかしセラミックスでは測定条件の最適化が遅れ，金属ほ ど簡単にはいかないのが現状であった，それでも本稿で紹

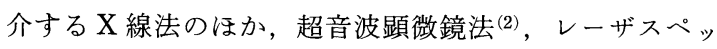
クル法, Indentation Fracture 法などの手法が試験されて きている。このらち X 線法は, 測定が非破壊的であり, セラミックス研削面でも適用可能, 垂直応力 · せん断応力 ・主応力などの各種応力值が定量できるなどの大きな特徵 をもつため，実用的な手法として最適である.

筆者らは, $\mathrm{X}$ 線束を直径 $0.1 \mathrm{~mm}$ まで微小化することに より接合界面近傍の詳細な残留応力分布測定を可能とし $\tau^{(3)(4)}$, 特異点近傍の最大主応力点, 接合界面に沿った分 布などの測定に適用し, 数值解析結果と比較議論してき

* (株)東芝新素材応用研究所主査

Measurement of Residual Stress Distribution around $\mathrm{Si}_{3} \mathrm{~N}_{4} /$ Steel Joined Interface Using $\phi 0.1 \mathrm{~mm}$ Collimated X-ray Beam; Shun-Ichiro Tanaka (New Materials Engineering Lab., Toshiba Corporation, Yokohama) Keywords: residual stress, joined interface, ceramic, silicon nitride, steel, X-ray, normal stress, shear stress, principal stress, singularity point, cutting, grinding, finite element method 1990 年 9 月 10 日受理
た (5). この他実際の製品で重要な接合体の切断・研削によ る残留応力再分布の把握 ${ }^{(6)}$ や, 切断面計測による内部分布 の推定の可能性 ${ }^{(7)}$ にいても検討している.ここでは窒化 ケイ素 $\left(\mathrm{Si}_{3} \mathrm{~N}_{4}\right)$ / 鉄鋼接合体における最近の測定結果を紹介 し，今後の課題にも触れたいと思う.

\section{2. $\mathbf{X}$ 線束微小化の効果と残留応力測定条件}

\section{（1） X 線による残留応力測定の原理}

$\mathrm{X}$ 線を用いた残留応力測定は, $\sin ^{2} \phi$ 法として金属材料 では確立された方法である. その測定原理は, 多結晶体に おける特定面間隔の応力による変化を, 様々な $\mathrm{X}$ 線入射 角度 $\phi$ に対する回折ピーク $(2 \theta)$ のシフトとして検出する ものであるが, 式 (1) に従って残留応力の絶対值が計算 される(8)(9).

$$
\begin{aligned}
\sigma_{\mathrm{R}} & =-\frac{E}{2(1+v)} \cdot \cot \theta_{0} \cdot \frac{\pi}{180} \cdot \frac{\partial(2 \theta)}{\partial\left(\sin ^{2} \psi\right)} \\
& =K \cdot \frac{\partial(2 \theta)}{\partial\left(\sin ^{2} \psi\right)}
\end{aligned}
$$

ここに, $\sigma_{\mathrm{R}}$ : 残留応力, $E$ : ヤング率, $v$ : ポアンン比, $\theta_{0}:$ 標準ブラッグ角 $(\mathrm{deg})$ である. $K$ は材料拈よび測定波 長により決まる定数(応力定数) である。 $2 \theta-\sin ^{2} \phi$ 直線の 傾きと $K$ の積で残留応力值が求まる.

表 1 セラミックスおよび鉄鋼の残留応力測定に用 いられる回折面.

\begin{tabular}{c|c|c|c}
\hline \hline $\mathrm{X}$-ray & $\mathrm{VK} \alpha$ & $\mathrm{Cr} K \alpha$ & $\mathrm{CuK \alpha}$ \\
\hline$\beta-\mathrm{Si}_{3} \mathrm{~N}_{4}$ & $2 \theta_{0}=152.67^{\circ}$ & $2 \theta_{0}=131.47^{\circ}$ & $2 \theta_{0}=141.45^{\circ}$ \\
& $d=0.1288 \mathrm{~nm}$ & $d=0.1256 \mathrm{~nm}$ & $d=0.0816 \mathrm{~nm}$ \\
\hline & & $(1,0,10)$ & $(416)$ \\
$\alpha-\mathrm{Al}_{2} \mathrm{O}_{3}$ & & $2 \theta_{0}=135.03^{\circ}$ & $2 \theta_{0}=136.11^{\circ}$ \\
& & $d=0.1239 \mathrm{~nm}$ & $d=0.0830 \mathrm{~nm}$ \\
\hline $\mathrm{ZrO}_{2}$ & & $(133)$ & $(026)$ \\
$(\mathrm{Y}-\mathrm{TZP})$ & & $2 \theta_{0}=152.09^{\circ}$ & $2 \theta_{0}=140.22^{\circ}$ \\
& & $d=0.1180 \mathrm{~nm}$ & $d=0.0819 \mathrm{~nm}$ \\
\hline $\mathrm{SiC}$ & & $(116)$ & $(306)$ \\
$(6 \mathrm{H})$ & & $2 \theta_{0}=121.69^{\circ}$ & $2 \theta_{0}=134.09^{\circ}$ \\
& & $d=0.1311 \mathrm{~nm}$ & $d=0.0837 \mathrm{~nm}$ \\
\hline$\alpha-\mathrm{Fe}$ & & $(211)$ & \\
& & $d=0.1170 \mathrm{~nm}$ & \\
\hline
\end{tabular}


残留応力の測定に用いられる回折面は高角度側の孤立ピ ークであることが望ましい。種々のセラミックスに対して 代表的な回折面をまとめると表 1 のようになる(8)(9). 本研 究に拈ける $\mathrm{Si}_{3} \mathrm{~N}_{4}$ 部の残留応力測定には, 侵入深さが小さ い $\mathrm{Cr} K \alpha$ 線を主に用い, $(212)$ 回折ピーク $\left(2 \theta_{0}=131.47^{\circ}\right)$ のシフトを観測した．な扮測定される残留応力値は $\mathrm{X}$ 線 の侵入深さにもよるが, 深さ約 $20 \mu \mathrm{m}$ までの表面近傍領 域に限られる. 以後測定された応力は表面残留応力値であ るが，界面近傍の表層に最も高い応力が残留することから も都合がよい。

\section{（2） $\mathbf{X}$ 線束微小化の効果}

セラミックス接合体または複合材に括けるX 線残留応 力実測の試みは今までも報告されていたが(10)(11)，照射面 積が最小でも $2 \mathrm{~mm}^{2}$ であり, 接合界面近傍のような微細 部の分布までは正確に評価できないと思われる。図1は窒 化ケイ素々軟鋼 (S45C) の角柱接合体界面中央の窒化ヶイ 素最近接部に拈ける残留応力値を, X 線照射面積を変え て測定した結果であるが，いずれの系でも残留応力値は照 射面積減少と共に増加し， $0.2 \mathrm{~mm}^{2}$ 以下で飽和する傾向に ある(6)(9). これは照射面積を $0.2 \mathrm{~mm}^{2}$ 以下にしないと応 力平均化効果のため真の応力値が得られないことを示して 扣り，この照射面積はX $\mathrm{X}$ 線の広がりも考慮して直径 0.3 $\mathrm{mm}$ 以下のコリメータを使用すべきことを意味する．すな わち接合界面や特異点近傍のように大きな応力勾配のある 箇所での測定はできるだけ微小径の X 線束を用いること が必要であり, 本研究では直径 $0.1 \mathrm{~mm}$ にコリメートした 高出力 $\mathrm{Cr} K \alpha$ 線を採用した.

な打 $\mathrm{X}$ 線束微小化の限界は, 照射面積内に結晶粒が 1000 2000個以上必要であるという測定原理からの要請 とX 線出力で決まり，対象とした窒化ケイ素などの一般

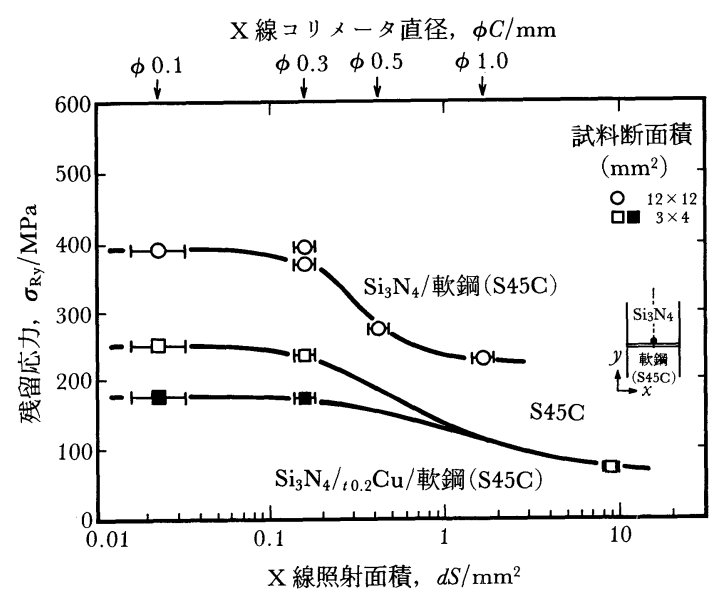

図 $1 \mathrm{X}$ 線法で測定された残留応力値の $\mathrm{X}$ 線照射面 積依存性 $\left(\mathrm{Si}_{3} \mathrm{~N}_{4} /\right.$ 軟鋼接合体, 測定位置は界面 に隣接する $\mathrm{Si}_{3} \mathrm{~N}_{4}$ 中央部).
的なセラミックスでは本条件が限界と思われる。また粒成 長した金属材料の溶接部などには微小束は適用できない。

図 1 亿おいて, 適正条件で得られた残留応力值は $\mathrm{Si}_{3} \mathrm{~N}_{4} /$ 軟鋼 $(\mathrm{S} 45 \mathrm{C})$ 系で $400 \mathrm{MPa}, \mathrm{Si}_{3} \mathrm{~N}_{4} / \mathrm{Cu}(t=0.2 \mathrm{~mm}) /$ 軟鋼系 で 180 240 MPa であり, この両者の差は $\mathrm{Cu}$ 板による残 留応力緩和効果に相当する．接合強度と残留応力との相関 で系統的に測定した結果と一致している(1)(4).

\section{（3）残留応力測定条件}

本研究では直径 $0.1 \mathrm{~mm}$ とコリメートした $\mathrm{Cr} K \alpha$ 線を用 いて残留応力分布を測定した．表 2 に 線残留応力測定 条件を示す。用いた X 線光学系では図 2 に示したように 照射面積は最大 $\left(\psi=35^{\circ}\right)$ でも $0.031 \mathrm{~mm}^{2}$ (長径 $0.33 \mathrm{~mm}$ ) である ${ }^{(9)}$.この值は残留応力の詳細分布を測定するには十 分微細化されていると考兄る. X 線出力は $5 \mathrm{~kW}$ としてコ リメートによる照射量減少を補った。式（1）に打ける応 力定数は $K=-883 \mathrm{MPa} /$ deg を用いたが，この值は窒化 ケイ素の物性值 $(E=285.0 \mathrm{GPa}, v=0.27)$ から計算したも ので, $\mathrm{X}$ 線的に求めた英らの值 $K=-986 \mathrm{MPa} / \mathrm{deg}^{(12)}$ と 良く一致する。

表 2 微小束 X 線による残留応力測定条件.

\begin{tabular}{l|l}
\hline \hline & $\mathrm{Si}_{3} \mathrm{~N}_{4}$ \\
測定装置 & Rigaku MXD \\
X 線 & $\mathrm{Cr} K \alpha, \mathrm{V}$-filter \\
& $50 \mathrm{kV}, 100 \mathrm{~mA}$ \\
בリメータ & $\phi 0.1 \mathrm{~mm}$ \\
照射面積 & $0.016 \sim 0.031 \mathrm{~mm}^{2}$ \\
$\phi$ 角度 & $5^{\circ}, 15^{\circ}, 20^{\circ}, 25^{\circ}, 30^{\circ}, 35^{\circ}$ \\
& 並傾法 \\
結晶格子面 & $\beta-\mathrm{Si}_{3} \mathrm{~N}_{4}(212)$ \\
& $2 \theta_{0}=131.47^{\circ}$ \\
応力定数 & $K=-882.8 \mathrm{MPa} / \mathrm{deg}$ \\
\hline
\end{tabular}

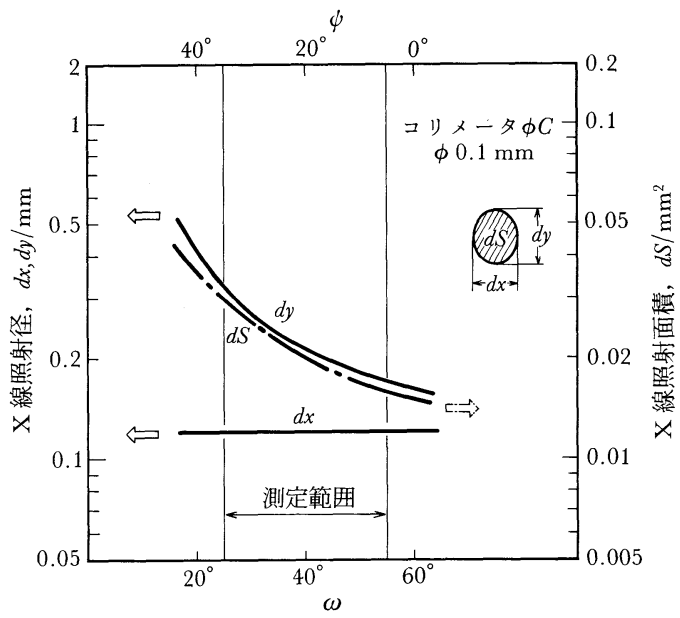

図 2 残留応力測定におけるX線照射径括よび面積 の $\mathrm{X}$ 線入射角 $\phi(\omega)$ 依存性 (コリメータ直径 $0.1 \mathrm{~mm}$ の場合). 


\section{（4）測定残留応力}

微小 $\mathrm{X}$ 線束で測定した残留応力は界面 $(\mathrm{x})$ および軸 $(\mathrm{y})$ 方向の垂直応力 $\sigma_{\mathrm{Rx}}, \sigma_{\mathrm{Ry}}$ のほか第 3 の垂直応力 $\sigma_{\mathrm{T}}(\pi / 4$ 方 向)である.この 3 種の垂直応力から, 式 (2)〜 (4)に従 って, せん断応力 $\tau_{\mathrm{Rxy}}$, 最大 $\cdot$ 最小主応力 $\sigma_{1}, \sigma_{2}$ を求める ことができる。

$$
\begin{aligned}
& \text { せん断応力 : } \tau_{\mathrm{Rxy}}=\sigma_{\mathrm{T}}-1 / 2\left(\sigma_{\mathrm{Rx}}+\sigma_{\mathrm{Ry}}\right) \\
& \text { 最大主応力 : } \sigma_{1}=1 / 2\left(\sigma_{\mathrm{Rx}}+\sigma_{\mathrm{Ry}}\right) \\
& +\sqrt{1 / 4\left(\sigma_{\mathrm{Rx}}-\sigma_{\mathrm{Ry}}\right)^{2}+\tau_{\mathrm{Rxy}}^{2}}
\end{aligned}
$$

最小主応力 : $\sigma_{2}=1 / 2\left(\sigma_{\mathrm{Rx}}+\sigma_{\mathrm{Ry}}\right)$

$$
-\sqrt{1 / 4\left(\sigma_{\mathrm{Rx}}-\sigma_{\mathrm{Ry}}\right)^{2}+\tau_{\mathrm{Rxy}}^{2}}
$$

\section{3. $\mathrm{Si}_{3} \mathrm{~N}_{4} /$ 鉄錀平板接合体界面近傍における残留応力微細 分布}

\section{（1）接合体形状および測定位置}

残留応力を測定した接合体は，厚さ $0.2 \mathrm{~mm}$ の $\mathrm{Cu}$ を残

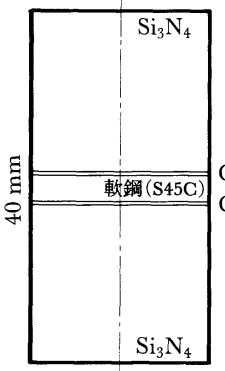

$20 \mathrm{~mm}$ 研削体

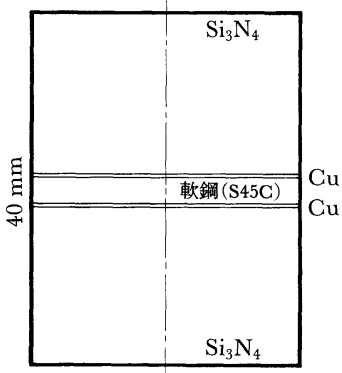

$30 \mathrm{~mm}$ 厚さ $3 \mathrm{~mm}$ ラップ体
図 3 残留応力を測定した $\mathrm{Si}_{3} \mathrm{~N}_{4} / \mathrm{Cu} /$ 軟鋼 $(\mathrm{S} 45 \mathrm{C})$ 平 板接合体試料形状.
留応力緩和材とし活性金属法で接合した $\mathrm{Si}_{3} \mathrm{~N}_{4}$ と軟鋼 (S45C) の接合体である(1)。接合強度は 4 点曲げで 350 $\mathrm{MPa}$ に達する ${ }^{(13)}$. 残留応力測定をした接合試験片の形状 を図 3 に示す. 主に幅 $20 \mathrm{~mm}$ の研削面 $\left(R_{\max } \leqq 1.0 \mu \mathrm{m}\right)$ を 有する接合体を測定したが，比較のために幅 $30 \mathrm{~mm}$ のラ ップ体も用いた.

幅 $20 \mathrm{~mm}$ の接合体では図 4 に示す位置で残留応力を測 定した。接合面に沿っては界面から 0.1, 0.5, $2.0 \mathrm{~mm}$ 離れ た線上を，軸方向には接合体両端から $0.1 \mathrm{~mm}$ 内側掞よび 中心軸線上を測定した. 特異点近傍すなわち接合端および

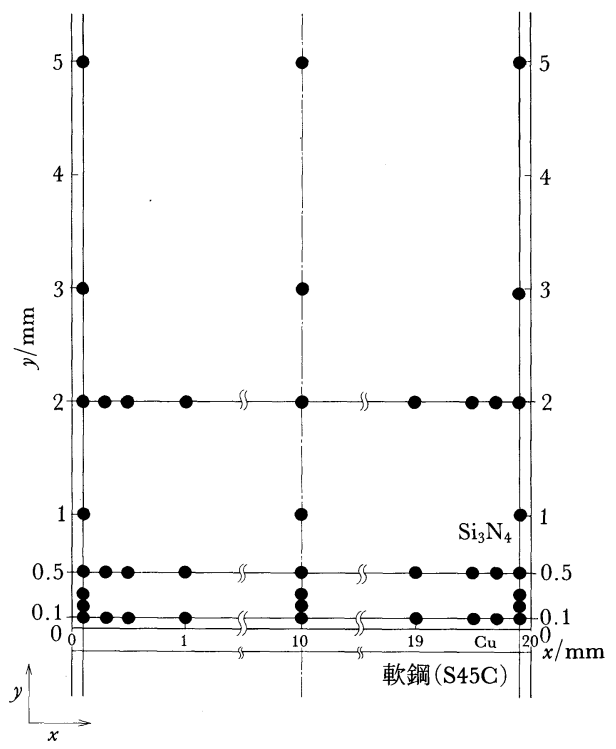

図 4 幅 $20 \mathrm{~mm}$ の接合体における残留応力測定位置 ( $\mathrm{O}$ 印, $\mathrm{Si}_{3} \mathrm{~N}_{4}$ 部, 研削体).
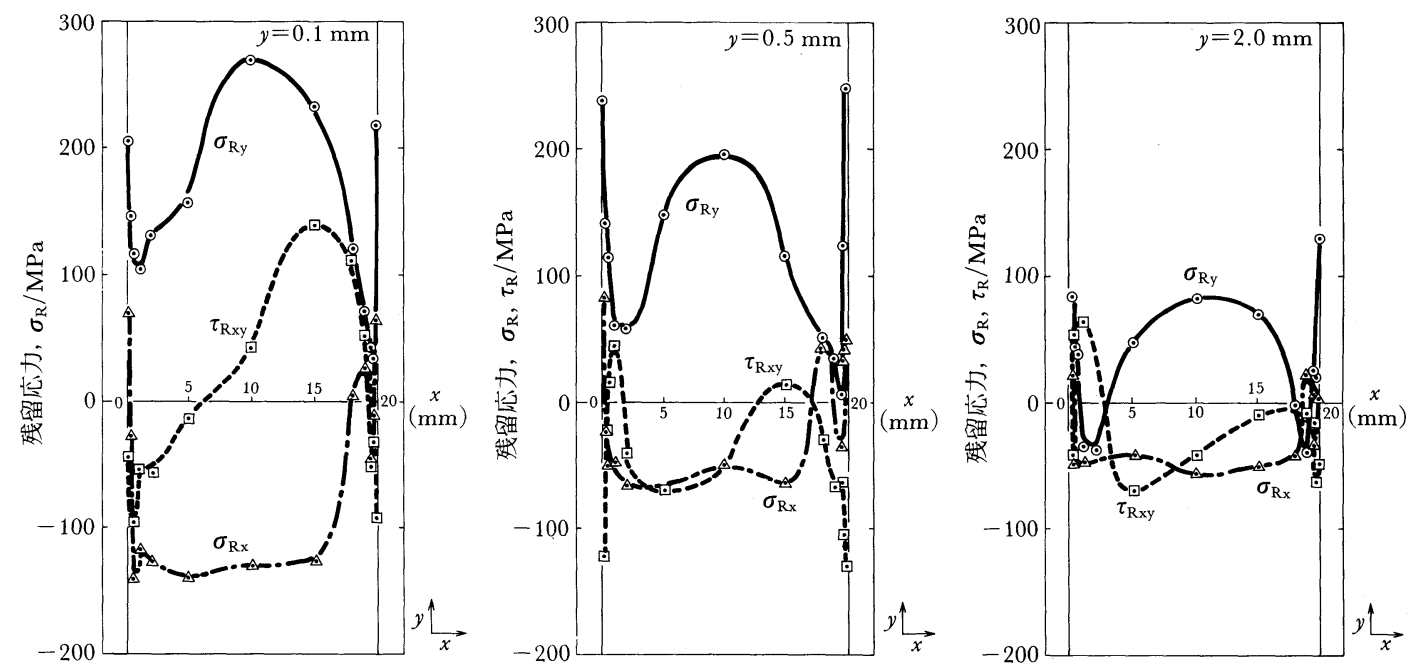

図 5 接合界面から0.1，0.5，2.0 mm 離れた線上に打ける垂直応力およびせん断応力分布測定結果. 
界面の極く近傍では測定間隔を $0.1 \sim 0.2 \mathrm{~mm}$ とし残留応 力分布を詳細に測定した.

\section{（2）界面近傍における垂直・せん断応力分布}

$\mathrm{Si}_{3} \mathrm{~N}_{4} / \mathrm{Cu} / \mathrm{S} 45 \mathrm{C}$ 接合体の $\mathrm{Si}_{3} \mathrm{~N}_{4}$ 部の界面近傍における 垂直応力拈よびせん断応力の分布を図 5 に示す(5). 図 5 は接合界面からの距離が順に $0.1,0.5,2.0 \mathrm{~mm}$ 離れた線上 における界面に沿った分布である．特異点である最両端で は，いずれの垂直応力も引張応力となり，特に $\sigma_{\mathrm{Ry}}$ が $200 \mathrm{MPa}$ を超える大きな值を示すのが特徵である．この 両端における大きな引張応力は広域 $\mathrm{X}$ 線照射(11)では観測 できなかったものである. 特異点から 0.5 1.0 $\mathrm{mm}$ 内側 に垂直応力, せん断応力の極小值が現れる。これは緩和層 $\mathrm{Cu}$ の局所的降伏によるものと解釈される. また接合端近 傍でみられる応力分布の微細構造は，3 次元効果が内部か ら現れていると考えられる。垂直応力 $\sigma_{\mathrm{Ry}}$ が試料中央部で 極大になる傾向が特徵的に見られるが，これは後述のよう に 2 次元の FEM 解析では予測がつかなかったものであ る.このような垂直応力分布は接合界面から $2.0 \mathrm{~mm}$ 離れ ても相似的に測定され，接合界面から相当広い領域まで残 留応力が緩和層の影響を受けていることが分かる．同様の 傾向は幅 $30 \mathrm{~mm}$ のラップ体でも図 6 の様にみられる ${ }^{(9)}$. また図 5 の $\sigma_{\mathrm{Rx}}$ には研削方向(本試料では軸方向) と垂直 方向に残留する圧縮応力が重畳していることが図 6 との 比較から推測される.

\section{（3）界面近傍における主応力分布}

垂直応力, せん断応力から変換して求めた最大主応力

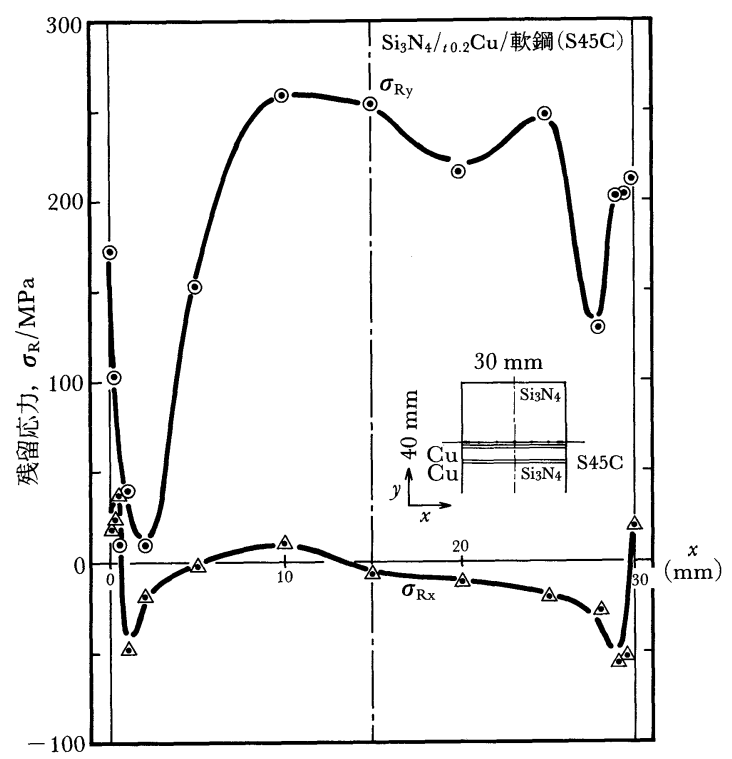

図 6 幅 $30 \mathrm{~mm}$ のラップ面をもつ接合体の界面に沿 垂直応力分布.

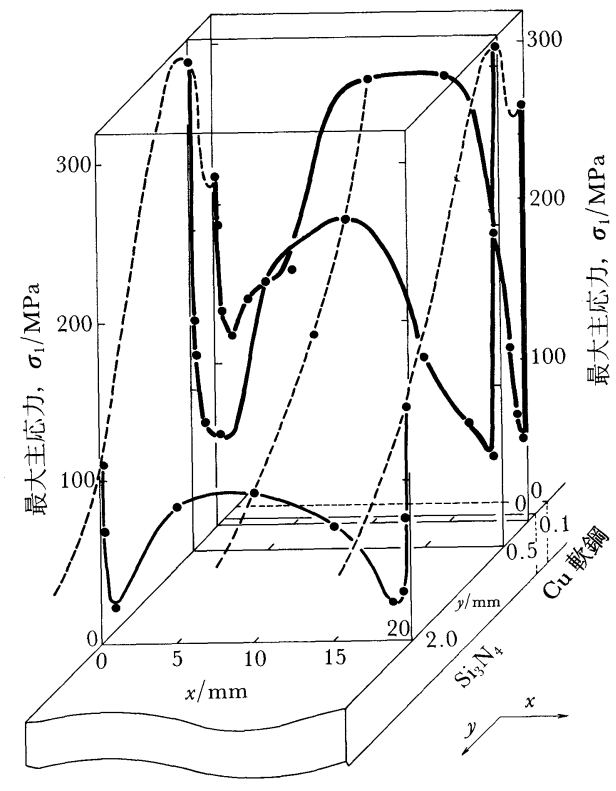

図 $7 \mathrm{Si}_{3} \mathrm{~N}_{4} / \mathrm{Cu} /$ 軟鋼接合体の接合界面近傍に打ける 最大主応力平面分布.

$\sigma_{1}$ の接合界面の沿った平面分布を図 7 に示す ${ }^{(5)}$. 図 5 の 垂直応力と同様の分布傾向にあるが，左右の非対称性が少 々見られる．試料の作製法によるものと思われる．軸方向 の最大主応力分布を強調した分布図を図 8 に示す. 接合端 角隅部の接合界面から約 $0.5 \mathrm{~mm}$ 離れた位置に最大主応力 が最大になる箇所が存在し, その応力值は $300 \mathrm{MPa}$ を超 えることが分かる. この測定結果は $\sigma_{1}$ が最大となる位置 に関する論争に一つの実験的な指針を与えるものとして注 目に值する. 一方, 接合体中央部に観察された最大主応力

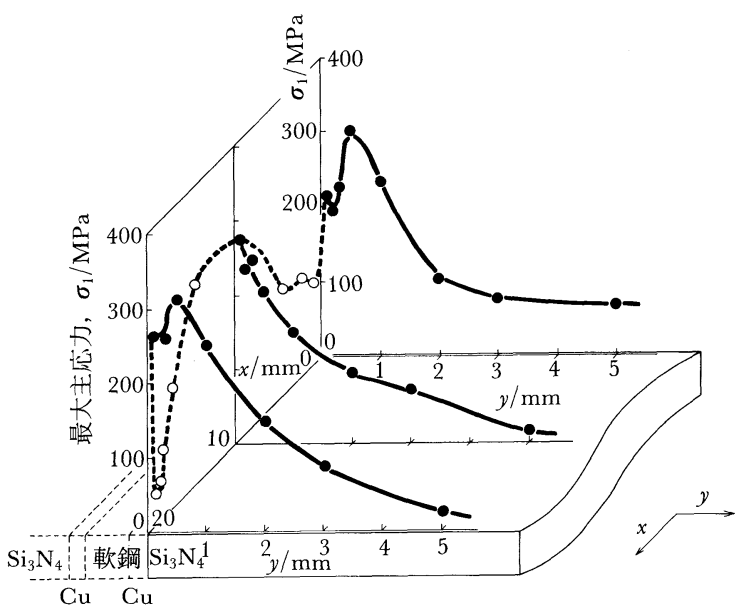

図 $8 \mathrm{Si}_{3} \mathrm{~N}_{4} / \mathrm{Cu} /$ 軟鋼接合体の軸方向に拈ける最大主 応力平面分布(両端では界面から約 $0.5 \mathrm{~mm}$ の 箇所に $\sigma_{1}$ 最大値). 
の極大値は接合界面において最大で, 界面から離れると共 に単調減少することが分かる.

この接合体の両端で最大主応力が最大となる箇所は, 七 ラミックスに熱衝撃により導入されたクラック起点の位置 に一致することが確認されている.な打外力による破壊起 点は接合界面での応力集中と残留応力の兼ね合いで決まる ため必ずしも最大主応力が最大となる箇所には一致しな い(1)(4)ことを注記しておく。

\section{4. 試験片切出しによる残留応力再分布}

一般に接合体は最終的に加工されて用いることが多いた め, 残留応力分布がある程度解放され, また再分布するこ とが予想される。ここでは $12 \mathrm{~mm} \times 12 \mathrm{~mm}$ の断面を持つ $\mathrm{Si}_{3} \mathrm{~N}_{4} / \mathrm{Cu} / \mathrm{S} 45 \mathrm{C}$ 接合体から図 9 の様に切断. 研削工程を 経て切り出した $3 \mathrm{~mm} \times 4 \mathrm{~mm}$ の断面をもつ接合試験片に 扣ける残留応力分布を詳細測定し, その再分布の特徵を把 握する。

切断後, 研削仕上げした接合体の界面近傍の垂直応力 · せん断応力分布を図10亿示す。測定位置は図 9 に示す様 に, 界面抢よび接合体両端から $0.1 \mathrm{~mm}$ 離れた線上の分布 である. 切出す前の $12 \mathrm{~mm} \times 12 \mathrm{~mm}$ 接合体の界面近傍に は図 5,6 と類似の残留応力分布が測定されている(6). 中 央の切断面側から $0.5 \mathrm{~mm}$ 内側に垂直応力の極小值が観測 され，もともと極大值を示していた中央部の分布が，切出 し試験片の特異点近傍に拈ける大きな引張応力として再分 布した様子が観測される，せん断応力は各々の接合体で対 称分布となることも注目される．最大・最小主応力分布は

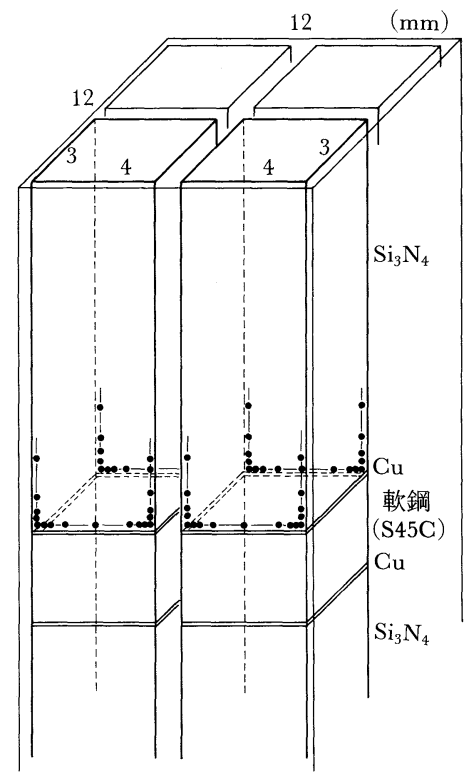

図 9 角柱接合体切り出し位置と残留応力再分布測 定位置.

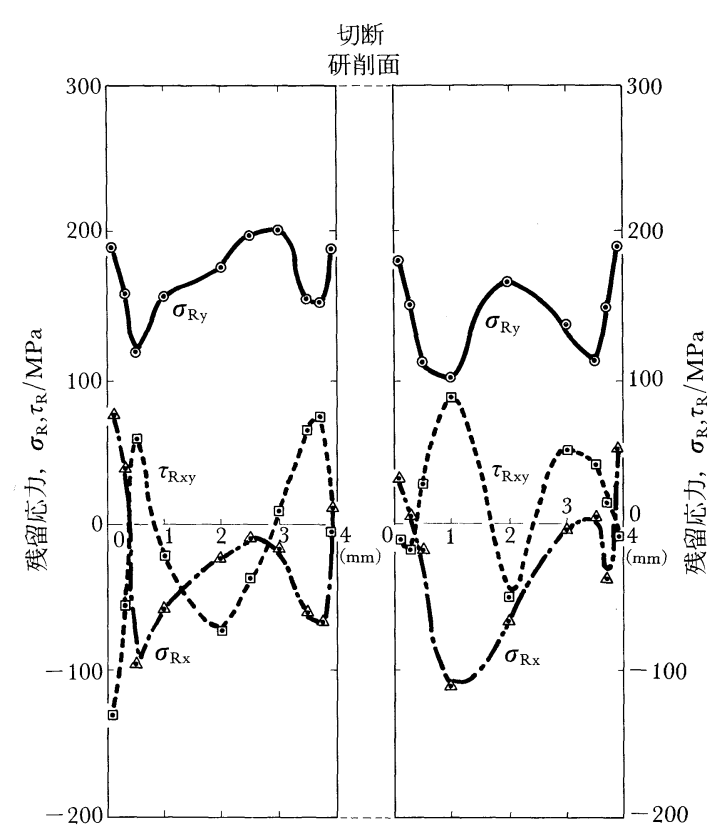

図10 $\mathrm{Si}_{3} \mathrm{~N}_{4} / \mathrm{Cu} /$ 軟鋼接合体の切断による垂直応力. せん断応力分布の変化.

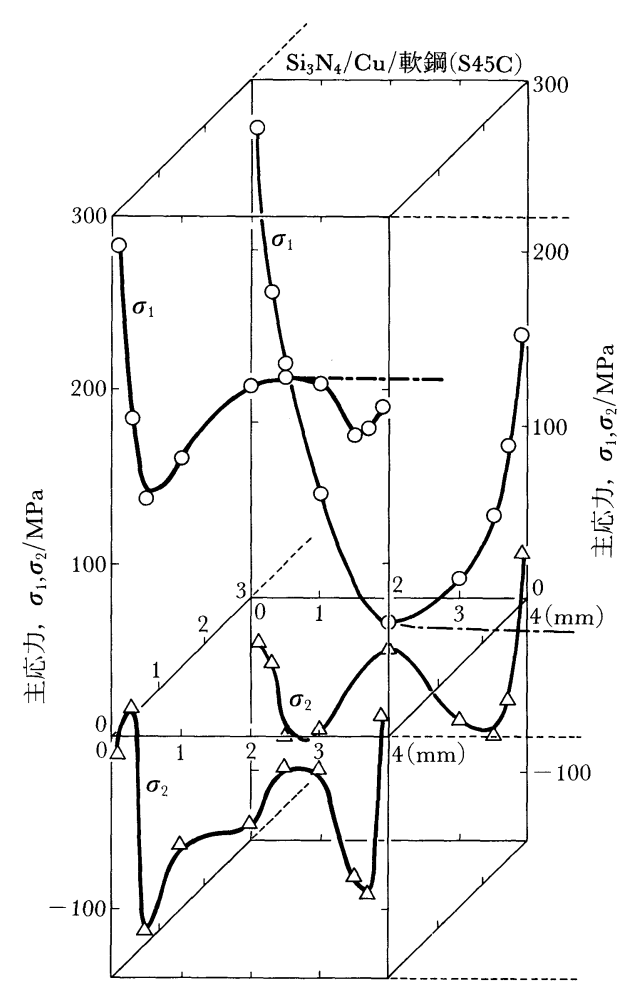

図11 角柱から切り出した接合体界面近傍における 主応力分布 (接合体内部の応力分布はある程度 保存される.). 
図11に示したが，表面側では図 7 と同様の傾向になる.

軸方向の最大主応力分布は図12に示すよらに，切断され た側でも接合端から $0.5 \mathrm{~mm}$ 離れた部位に最大值が現れる ように再分布することは注目に値する。図 8 での単調減 少分布と比較すると明確である.

\section{5. 残留応力分布の生成機構}

\section{(1) FEM 解析結果との比較}

微小束 X 線法により金属/七ラミックス接合体界面近傍 で実測された残留応力分布につき熱応力の数值解析結果に より検討を加える. 今回平板接合体で測定された残留応力 は，表面に打ける值であり，3 次元解析結果と比較しなけ

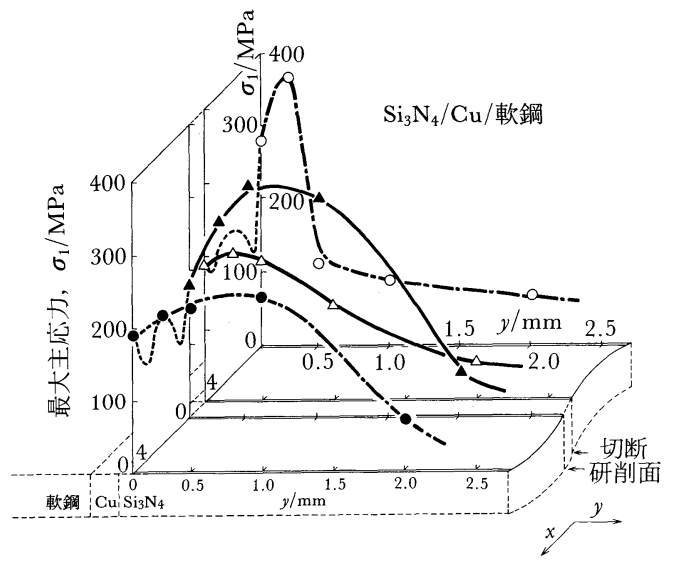

図12 $\mathrm{Si}_{3} \mathrm{~N}_{4} / \mathrm{Cu} /$ 軟鋼接合体の切断に上る軸方向最大 主応力分布の変化.
ればならない. 2 次元解析に扣ける平面応力状態の分布は 接合体内部のそれであり，測定分布とは比較できない，汎 用解析コードABAQUS を用いて弾性解析で求めた計算結 果を図13に示す (14). A は 2 次元弾性解析結果(内部), B は 3 次元弾性解析結果(表面)である. 解析は分割要素数 2400 の 2 次要素を用い, $873 \mathrm{~K}$ での無応力状態から室温 まで均一降温することを仮定して行った，図13-B は接合 界面から $0.3 \mathrm{~mm}$ 離れた線上の垂直応力およびせん断応力 分布である. 弾性計算のため応力值は過大評価されている が，全体の傾向は図 5 に示した測定結果とよく一致する 傾向にある．接合体中央部における表面残留応力極大値は 冷却時の試料内外の温度差に起因するものではなく，接合 体内部からの 3 次元効果の現れであり接合体固有の分布 と解釈される。また接合端またはその内側における応力值 の微細変化も解析結果に現れており，本質的なものと思わ れる. 同様な傾向は切出した試験片での残留応力再分布測 定結果図10にも現れている. 数値解析結果図13-B は緩和 層 $\mathrm{Cu}$ の塑性変形を考慮した 3 次元弾塑性解析結果により 更に精度が向上すると予想される。

\section{（2）接合体内部の残留応力分布の推定}

$12 \mathrm{~mm} \times 12 \mathrm{~mm}$ の接合体から切り出した試験片におい て，もともと中心部であった面内の接合界面に沿う最大主 応力分布は, 内部の残留応力分布を反映しているかを検討 してみる. 図11の内側に拈ける応力分布測定結果は, 2 次 元解析結果図13-A と定性的に一致している. 切断. 研削 により新しく現れた接合端では大きな引張応力に再分布し ているが，接合体内部の分布はある程度保存されて現れる ことは特筆すべきと考える。
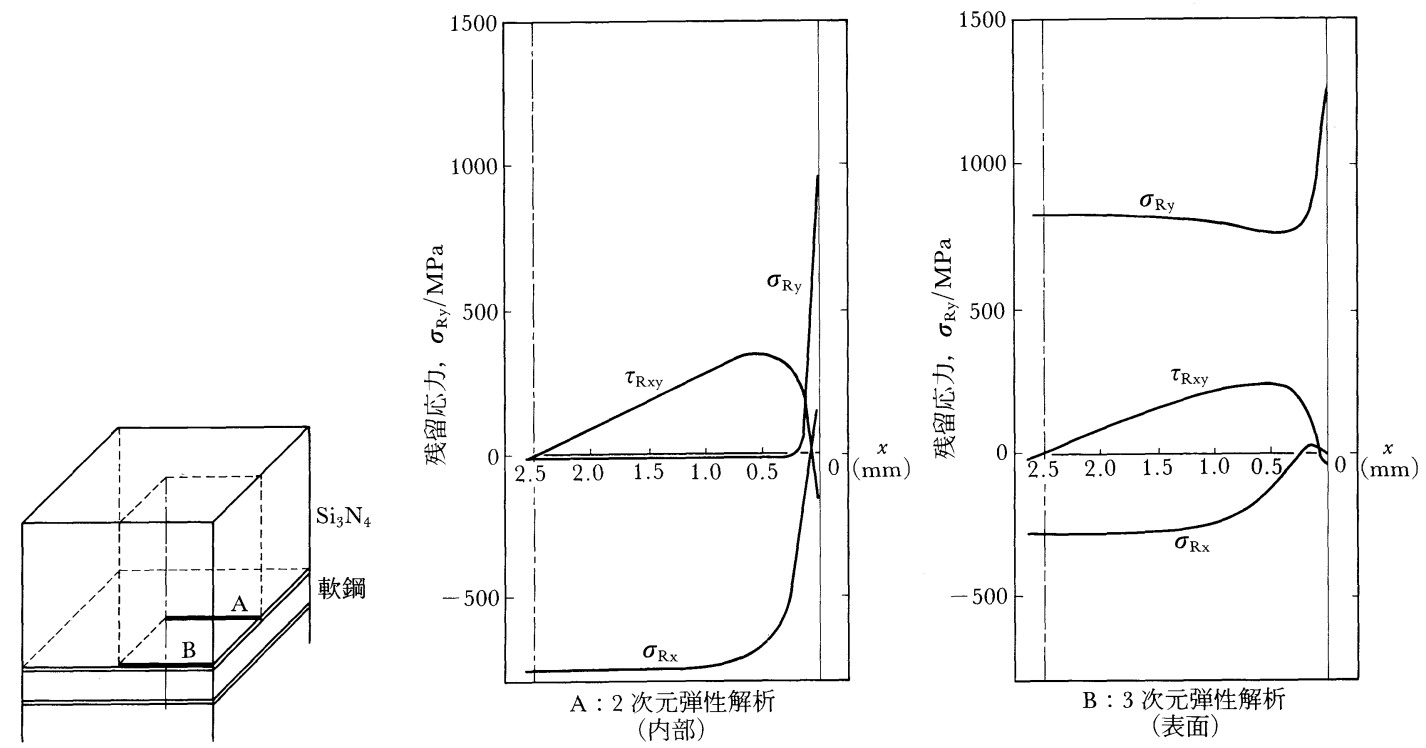

図13 有限要素法による $\mathrm{Si}_{3} \mathrm{~N}_{4}$ /軟鋼接合体表面および内部の残留応力解析結果 (弾性解析, $\mathrm{A}: 2$ 次元, B : 3 次元). 
6. あとがき

直径 $0.1 \mathrm{~mm}$ にコリメートした高出力微小束 $\mathrm{X}$ 線を用 いることにより, 金属/七ラミックス接合体界面近傍のセ ラミックス部に打ける表面残留応力を $0.03 \mathrm{~mm}^{2}$ 以下の領 域まで詳細に測定することができるよらになった，本手法 を $\mathrm{Si}_{3} \mathrm{~N}_{4} / \mathrm{Cu} / \mathrm{S} 45 \mathrm{C}$ 接合界面に適用した結果，接合端特異 点近傍における $200 \mathrm{MPa}$ に達する引張応力, 特異点から 0.5 1.0 mm 内側に垂直応力 - 世九断応力の極小值 (緩和 層 $\mathrm{Cu}$ の局所的降伏による), 接合体中央部で極大となる 軸方向の垂直応力 (内部からの 3 次元効果) など従来測定 できなかった詳細分布が明らかになり，3 次元 FEM 解析 結果との比較検討が可能になった. また接合特異点から約 $0.5 \mathrm{~mm}$ 離れた箇所に現れる最大主応力の最大点は, 熱衝 撃により導入された $\mathrm{Si}_{3} \mathrm{~N}_{4}$ 部のクラック起点に一致し, 数 値解析に打ける課題に一応の結論を与えることができたと 信じている.ささらに接合体の切断・研削による残留応力の 再分布が明確になり，不可能に近かった接合体内部に拈け る分布を推測することもできるよらになったこともこの分 野の大きな進歩であると確信している.

更に本技術は実際の接合製品の非破壊検査手法としてだ けでなく, 連続体の力学や数値解析結果の検証にも用いる ことができる．また接合強度との相関も明確になり，応力 集中効果把握と共に信頼性保証の手段ともなろら.今後は 超音波顕微鏡など他の手法との相補的な適用が接合界面近 傍の残留応力測定には必要と考えている.

\section{文献}

(1) 例えば S. Tanaka: Proc. MRS Int'l. Mtg. on Adv. Mats., 8(1989), 125.

（2）三浦一真, 成田敏夫, 石川達雄, 石川 潔 : 日本金属学 会秋期講演概要， $(1989 \cdot 10)$, p. 118.

（3）田中俊一郎，小木曾克彦：日本材料学会第25回 X 線材 料強度に関するシンポジウム講演論文集, $(1988 \cdot 7), \mathrm{p}$. 213.

（4）田中俊一郎：日本材料学会第25回 X 線材料強度に関す る討論会，講演論文集，(1988 · 12), p. 70 .

（5）田中俊一郎, 高橋由美子; 日本金属学会秋期大会講演概 要, $(1989 \cdot 10)$, p. 116.

（6）田中俊一郎：日本材料学会第27回 X 線材料強度に関す るシンポジウム講演論文集, $(1990 \cdot 7)$, p. 167.

（7）田中俊一郎：日本金属学会春期講演概要, (1990 - 4), p. 456.

（8）日本材料学会 $\mathrm{X}$ 線材料強度部門委員会編, $\mathrm{X}$ 線応力測 定法標準 (1982).

(9) S. Tanaka and Y. Takahashi: ISIJ International, 30 (1990) No. 12 in press.

(10) O. T. Iancu, D. Munz, B. Eigenmann, B. Scholtes and E. Macherauch; J. Amer. Ceram. Soc., 73 (1990), 1144.

（11）栗田政則, 井原郁夫, 佐藤 誠, 斎藤 明, 福沢 康, 田中俊一郎：日本機械学会論文集 (A 編), 56 (1990), 298.

（12）英 崇夫ら; 日本材料学会第23回 X 線材料強度に関す るシンポジウム講演論文集, $(1987 \cdot 7)$, p. 219.

(13) S. Tanaka: Proc. MRS Int'l. Mtg. on Adv. Mats., 8(1989), 91.

（14）川村法靖, 川上 崇, 那波隆之, 田中俊一郎：未発表.

\section{ろう接研究の課題}

セラミックス/金属の接合をろう接によって行う，つま り接合の区分としてろら接法を挙げるとこれまでの接合研 究の大部分がこの中に含まれる．万ら接による接合は大き く分けると二つの方法に分けることができる，第一はセラ ミックス表面に複合金属ペーストを塗布した後，焼成して メタライズ層を形成してろら接を行ら方法, 第二は活性金 属をろら材の中に添加, あるいはセラミックス表面に付着 (メッキ，蒸着などによる)させてろら接を行ら方法であ る.さらにこれらはセラミックスの種類(酸化物系, 非酸 化物系), 圧力の有無, 活性金属の種類などにより分類整 理する事ができる．これらの学協会での研究発表件数はこ の一年間でおよそ200件以上になると思われる。このらち 活性金属を用いる方法がその内の $70 \%$ 以上を，またセラ ミックスでは近年の傾向としてやはり非酸化物系が酸化物 系に比較して70\%以上になるものと思われる，活性金属 法が多い理由としては，接合が直接的でありこれまでの金
属/金属の接合と同様な手軽さで行えることであろら．活 性金属としては Ti, Zr が中心でそれに $\mathrm{Co}, \mathrm{Ce}, \mathrm{Ca}, \mathrm{V}, \mathrm{Nb}$, Hf, Ta，などの元素を添加している。いずれも接合界面で の活性金属とセラミックスの反応により接合が行われる.

これまでの研究発表で, 既にほとんどのセラミックスが登 場し，活性金属を用いれば何とか接合体は得られることが ほぼ確認されたと思われる。しかしながらセラミックス/ 金属接合が求めている期待にはまだ程遠いよらであり，こ の点から考えるとセラミックス/金属の接合はやっと入り ロにたどり着いた程度ではないかと思われる。

セラミックス/金属のろら接は単に接合によって構造物 を作るだけではなく，金属体強化のためにセラミックスフ アイバーをマトリックスに埋め込む際の界面機構など，そ の応用は広く是非ともこの問題が解決されなければならな い分野である。

（東海大工学部金属材料学科 有賀 正） 